\title{
Effect of ocean acidification on early life stages of Atlantic herring (Clupea harengus L.)
}

\author{
A. Franke and C. Clemmesen \\ Department of Marine Ecology, Leibniz-Institute of Marine Sciences (IFM-GEOMAR), Düsternbrooker Weg 20, 24105 Kiel, \\ Germany
}

Received: 1 July 2011 - Published in Biogeosciences Discuss.: 18 July 2011

Revised: 30 November 2011 - Accepted: 2 December 2011 - Published: 15 December 2011

\begin{abstract}
Due to atmospheric accumulation of anthropogenic $\mathrm{CO}_{2}$ the partial pressure of carbon dioxide $\left(p \mathrm{CO}_{2}\right)$ in surface seawater increases and the $\mathrm{pH}$ decreases. This process known as ocean acidification might have severe effects on marine organisms and ecosystems. The present study addresses the effect of ocean acidification on early developmental stages, the most sensitive stages in life history, of the Atlantic herring (Clupea harengus L.). Eggs of the Atlantic herring were fertilized and incubated in artificially acidified seawater $\left(p \mathrm{CO}_{2} 1260,1859,2626,2903,4635 \mu \mathrm{atm}\right)$ and a control treatment $\left(~ p \mathrm{CO}_{2} 480 \mu \mathrm{atm}\right)$ until the main hatch of herring larvae occurred. The development of the embryos was monitored daily and newly hatched larvae were sampled to analyze their morphometrics, and their condition by measuring the RNA/DNA ratios. Elevated $p \mathrm{CO}_{2}$ neither affected the embryogenesis nor the hatch rate. Furthermore the results showed no linear relationship between $p \mathrm{CO}_{2}$ and total length, dry weight, yolk sac area and otolith area of the newly hatched larvae. For $p \mathrm{CO}_{2}$ and RNA/DNA ratio, however, a significant negative linear relationship was found. The RNA concentration at hatching was reduced at higher $p \mathrm{CO}_{2}$ levels, which could lead to a decreased protein biosynthesis. The results indicate that an increased $p \mathrm{CO}_{2}$ can affect the metabolism of herring embryos negatively. Accordingly, further somatic growth of the larvae could be reduced. This can have consequences for the larval fish, since smaller and slow growing individuals have a lower survival potential due to lower feeding success and increased predation mortality. The regulatory mechanisms necessary to compensate for effects of hypercapnia could therefore lead to lower larval survival.
\end{abstract}

\section{Correspondence to: $\mathrm{C}$. Clemmesen} (cclemmesen@ifm-geomar.de)
Since the recruitment of fish seems to be determined during the early life stages, future research on the factors influencing these stages are of great importance in fisheries science.

\section{Introduction}

The atmospheric $\mathrm{CO}_{2}$ concentration is constantly increasing primarily due to human activities causing an acidification of the ocean (Feely et al., 2004). While the $\mathrm{CO}_{2}$ concentration ranged between 180 and $300 \mathrm{ppm}$ over the last 650000 years (Siegenthaler et al., 2005), the recent global mean is $\sim 390 \mathrm{ppm}$ (Conway and Tans, 2011). A further rise up to $\sim 790 \mathrm{ppm}$ until the end of the century is predicted; as a result the seawater carbonate chemistry is changing and the present mean surface $\mathrm{pH}_{\mathrm{T}}$ of $\sim 8.1$ is expected to decrease by $\sim 0.3$ units (Gattuso and Hansson, 2011; Orr, 2011). However, there are naturally $\mathrm{CO}_{2}$ enriched habitats such as upwelling regions (Feely et al., 2008). In the Baltic Sea acidification of coastal surface waters occurs as a result of its strong seasonal stratification, which is causing hypoxia in deeper water layers and subsequent upwelling of $\mathrm{CO}_{2}$-enriched waters (Thomsen et al., 2010). In our study area, the Kiel Fjord, the $p \mathrm{CO}_{2}$ is elevated for large parts of the year with peak values of $>2300 \mu$ atm during late summer, which could increase to $>4000 \mu \mathrm{atm}$ in the future according to simple model calculations (Thomsen et al., 2010).

Studies reporting the potential impact of ocean acidification on marine organism have focussed on calcifying organisms (e.g., Langdon, 2002; Fabry, 2008). Furthermore, a variety of physiological traits of non-calcifiers such as acidbase regulation, metabolic rate and growth under elevated $\mathrm{CO}_{2}$ concentrations have been analysed (Larsen et al., 1997;

Published by Copernicus Publications on behalf of the European Geosciences Union. 
Michaelidis et al., 2007; Gutowska et al., 2010; Hu et al., 2011) and reviewed (Pörtner et al., 2004; Ishimatsu et al., 2008; Pörtner and Peck, 2010). By using meta-analytic techniques it has been shown that the biological effects of ocean acidification are negative yet variable amongst organisms (e.g., Kroeker et al., 2010). It is hypothesised that the response of marine organisms to acidified seawater does not only vary between different groups of organisms, but also at the species level generating ecological winners and losers (Doney et al., 2009; Ries et al., 2009). Generally, organisms with efficient acid-base regulatory mechanisms e.g. fish and cephalopods are found to be less adversely affected. However, early life history stages even of the more tolerant taxa are assumed to be most susceptible to ocean acidification (Raven et al., 2005; Melzner et al., 2009). Considering that they are generally known to be most affected by abiotic conditions such as oxygen availability, temperature and salinity (Blaxter, 1956; Rosenthal and Alderdice, 1976), particular importance should be given to the potential effect of acidified seawater on their development. Most studies on the influence of ocean acidification on early life stages have been conducted on invertebrates such as molluscs, crustaceans and echinoderms (e.g., Dupont et al., 2010) indicating that its impact is highly variable amongst different species, even within closely related taxa (Dupont and Thorndyke, 2009).

So far only very few studies on the effect of hypercapnia on early developmental stages of marine teleosts, using $p \mathrm{CO}_{2}$ concentrations in the range of future predictions, have been published (Checkley et al., 2009; Munday et al., 2009, $2011 \mathrm{a}, \mathrm{b}$ ). Higher $p \mathrm{CO}_{2}$ levels (up to $150000 \mu \mathrm{atm}$ ) were used by Kikkawa et al. (2003) to investigate the acute lethal effect of $p \mathrm{CO}_{2}$ on early life stages of marine fishes.

In this study we examined to what extent elevated $p \mathrm{CO}_{2}$ concentrations affect the embryonic development and the condition of newly hatched larvae of the Atlantic herring, a teleost fish of major commercial importance in the Baltic Sea. We tested whether acidified conditions influence the embryogenesis and hatch rate as well as morphometrics, otolith area and RNA/DNA ratio of newly hatched herring larvae.

\section{Materials and methods}

\subsection{Experimental setup and water chemistry}

Adult Atlantic herring from a local spring-spawning stock were caught in Kiel Fjord, one of the most important spawning grounds in the Western Baltic Sea, in April 2007. The gametes of 3 females and 3 males with a total length of $28 \mathrm{~cm}$ each were used to perform a laboratory experiment in filtered $(0.5 \mu \mathrm{m})$ and UV sterilized seawater from Kiel Fjord (salinity 14.0) in a temperature constant room set at $12{ }^{\circ} \mathrm{C}$ with a day/night cycle of $12 / 12 \mathrm{~h}$.
We used 101 gas-proof high-density polyethylene (HDPE) containers firmly closed with lids as experimental units for egg incubation. A centrifugal pump (1005 21-5 Eheim) was attached to every container with one tube each plugged in the aspiration port and the discharge port going through the container lid ensuring a constant water circulation within the sealed systems to avoid fungal infestation on the eggs. Temperature, oxygen content and $\mathrm{pH}_{\mathrm{F}}$ (free scale) were measured daily in each experimental unit (WTW Multi 350i with SenTix 21 electrode). The $\mathrm{pH}$ meter was calibrated by a threepoint calibration procedure with NBS buffer solutions of $\mathrm{pH}$ 4.01, 7.00 and 10.00 (WTW TEP Trace). The incubation temperature (mean \pm standard deviation: $13.6 \pm 0.4^{\circ} \mathrm{C}$ ) was above the set room temperature due to the heat production of the centrifugal pumps.

Before starting the experiment total dissolved inorganic carbon $\left(C_{\mathrm{T}}\right)$, total alkalinity $\left(A_{\mathrm{T}}\right)$, temperature and salinity of the stock seawater were determined. $C_{\mathrm{T}}$ was measured photometrically in duplicate after Stoll et al. (2001) using a Bran \& Lübbe Quattro Analyzer equipped with a XY-2 autosampler. $A_{\mathrm{T}}$ was measured in duplicate through potentiometric titration after Dickson (1981) with a Metrohm Titrando 808. To quantify the measurement accuracy of $C_{\mathrm{T}}$ and $A_{\mathrm{T}}$ certified reference material (provided by A. G. Dickson, Scripps Institution of Oceanography) was used.

We set up 6 different treatment levels (in 4 replicates) composed of a control treatment (non-manipulated Baltic Sea water) and 5 treatment levels with elevated $p \mathrm{CO}_{2}$ concentrations. The different concentrations were adjusted by decreasing $A_{\mathrm{T}}$ at constant $C_{\mathrm{T}}$ through the addition of a strong acid $(1 \mathrm{M} \mathrm{HCl})$, according to the Guide to best practices for ocean acidification research and data reporting (Gattuso et al., 2010) one of the most useful techniques to manipulate the seawater chemistry, despite the fact that it does not fully mimic future changes in the carbonate system.

At the beginning, intermediate phase and end of the experiment water samples for $C_{\mathrm{T}}$ and $A_{\mathrm{T}}$ measurements were taken in each experimental unit and processed as described above. Unfortunately, the $C_{\mathrm{T}}$ water samples could not be used due to problems during storage. Thus, the carbonate system was calculated with the CO2SYS macro for low salinities (modified by Körtzinger after Pierrot et al., 2006) using the measured $A_{\mathrm{T}}$ and $\mathrm{pH}_{\mathrm{F}}$ values. The dissociation constants $\mathrm{K}_{1}$ and $\mathrm{K}_{2}$ according to Roy et al. (1993) were used.

To reduce the chance of low quality gametes and to simulate natural variability, we incubated eggs from all 3 females in each experimental unit. 50 eggs of each female were strip-spawned on a plastic plate (48 plates in total, each $9 \mathrm{~cm} \times 2.5 \mathrm{~cm}$ ). The eggs of every female were arranged in a single row to ensure equal gas exchange and comparable environmental conditions. Fertilization was performed in water of the respective treatment level adding a sperm mixture of 3 males. Subsequently, 2 plates each (plate 1 and plate 2 ) were put in a holder at the bottom of every HDPE container. Fertilization rates were determined $2 \mathrm{~h}$ later for every plate under a 
stereomicroscope (Leica MZ8). From the second day on eggs of plate 1 were photographed daily with a Canon Digital Ixus camera connected via $\mathrm{C}$-mount to a stereomicroscope (Leica MZ8) to monitor the embryonic development, to determine the proportion of malformed eggs and the overall egg mortality. Plate 2 was not taken out of the containers at any time during the course of the experiment.

To reduce the drift from the originally set $p \mathrm{CO}_{2}$ levels due to respiration of the eggs, $40 \%$ of the water was exchanged at day 6 in every experimental unit by using stock seawater (non-manipulated and adjusted to the different $\mathrm{CO}_{2}$ concentrations, respectively) which was stored in completely filled and sealed plastic containers at $12^{\circ} \mathrm{C}$ since the beginning of the experiment.

\subsection{Analysis of eggs and larvae}

After the main hatch occurred, yolk sac larvae were transferred into $1.5 \mathrm{ml}$ Eppendorf safe-lock tubes with seawater and frozen at $-70^{\circ} \mathrm{C}$. Hatch rate was determined by counting empty eggshells under a stereomicroscope (Leica MZ8). For the following analysis, larvae were thawed and photographed with a QImaging MicroPublisher 3.3 RTV camera connected via C-mount to a stereomicroscope (Leica MZ95) in order to measure the total length and the yolk sac area using the program UTHSCSA Image Tool 3.0.

To determine the dry weight, larvae were rinsed in distilled water to avoid salt residues, put individually in $1.5 \mathrm{ml}$ Eppendorf safe-lock tubes and freeze-dried (Christ Alpha 14 freeze-drier) for $16 \mathrm{~h}$ at $-55^{\circ} \mathrm{C}$. They were subsequently weighed to the nearest $0.1 \mu \mathrm{g}$ (Sartorius microbalance SC2) and either used for removal of otoliths or biochemical analysis.

For otolith removal, larvae were put in a drop of distilled water on a microscope slide. Right and left sagittae and lapilli were dissected under a stereomicroscope (Leica MS5) equipped with a polarizing filter using 2 fine dissecting needles and fixed with clear nail polish. Digital pictures of the otoliths were taken at 1250x magnification using a microscope (Leitz Laborlux S) equipped with a QImaging MicroPublisher 3.3 RTV camera. Sagitta and lapillus areas were measured with the image analysis software Image-Pro Plus 5.0.

Larvae were analysed for RNA and DNA concentrations using a modification of the method of Clemmesen (1993) and Belchier et al. (2004) as described in Malzahn et al. (2007). For the determination of RNA/DNA ratios, nucleic acids were quantified fluorometrically in a microtitre fluorescence reader (Labsystems, Fluoroskan Ascent) using ethidium bromide as a fluorophore. At first total nucleic acids were measured and subsequently RNase (Serva, Ribonuclease A) was applied. For RNA and DNA calibrations 16S and 23S rRNA (Boehringer 206938) and Lambda DNA (Boehringer 745782), respectively, were used. RNA amounts were calculated using the RNA standard calibration curves. DNA amounts were calculated using the relationship between RNA and DNA fluorescence described by Le Pecq and Paoletti (1966) resulting in a slope ratio of 2.2 (Caldarone et al., 2006).

\subsection{Statistical analysis}

Since the experiment was set up to evaluate a broad range of $p \mathrm{CO}_{2}$ levels, linear regression analysis was the statistical method of choice. Statistical analyses were performed using the software Statistica 6.1 (StatSoft, Inc.). All data were tested for normality using the Shapiro-Wilk test. Nonnormally distributed data were log-transformed and percentage data were arcsine transformed prior to linear regression analysis. Data were tested for homogeneity of variances using Levene's test if a significant linear relationship was found. The difference between right and left otolith areas (sagitta and lapillus, respectively) was analyzed using a paired t-test after data were tested for normality and homogeneity of variances. Since no difference between right and left otolith areas was observed, the data were combined and the resulting mean values were used for linear regression analysis. We also calculated effect sizes and $95 \%$ confidence intervals around effect sizes using the results from control ( $\left.p \mathrm{CO}_{2} 480 \mu \mathrm{atm}\right)$ and highest treatment $\left(p \mathrm{CO}_{2} 4635 \mu \mathrm{atm}\right)$ applying the methodology of Hedges and Olkin (1985). Results are reported as mean \pm standard deviation (SD).

\section{Results}

We incubated herring eggs at 6 mean $p \mathrm{CO}_{2}$ values of $480 \pm 81,1260 \pm 218,1859 \pm 240,2626 \pm 197,2903 \pm 204$ and $4635 \pm 340 \mu \mathrm{atm}$ (corresponding to $\mathrm{pH}_{\mathrm{F}}$ values between $8.08 \pm 0.07$ and $7.05 \pm 0.03$ ) until the main hatch occurred (Table 1). The mean oxygen saturation was above $80 \%$ in all cases until the end of the experiment.

Fertilization was successful, resulting in rates between 86 and $90 \%$ at all treatment levels. Neither the daily observation of the herring eggs nor the evaluation of the daily taken digital photographs showed any difference or time delay in the embryonic development between the 6 treatment levels. The herring embryos showed the same stage of development regarding blastoderm formation, epiboly, appearance of eyes and myomeres, beginning of embryonic movement, heart pulsation, eye pigmentation, appearance of otoliths and main hatch at the respective time of monitoring.

There was neither a significant linear relationship between the $p \mathrm{CO}_{2}$ level and the incidence of embryonic malformations such as deformation and irregular cleavage of blastomeres (Fig. 1a; $r^{2}=0.02, P=0.52$ ), nor the mortality rate during the embryonic development (Fig. $1 \mathrm{~b} ; r^{2}=0.02$, $P=0.53$ ).

There was no effect on the embryonic duration, since the main hatch occurred during the night of day 8 at all $p \mathrm{CO}_{2}$ 
Table 1. Seawater carbonate system speciation for the different treatment levels during the course of the experiment. Variables were calculated using measured $\mathrm{pH}_{\mathrm{F}}, \mathrm{A}_{\mathrm{T}}$, salinity (14.0) and temperature $\left(13.6 \pm 0.4^{\circ} \mathrm{C}\right)$ of the respective replicates at the beginning, in the middle and at the end of the experiment. Values are means \pm SD.

\begin{tabular}{|c|c|c|c|c|c|c|c|c|}
\hline \multirow[b]{2}{*}{ Treatment } & \multicolumn{2}{|c|}{ Seawater measurements } & \multicolumn{6}{|c|}{ Calculations } \\
\hline & $\begin{array}{l}\mathrm{pH}_{\mathrm{F}} \\
\text { (free scale) }\end{array}$ & $\begin{array}{l}\mathrm{A}_{\mathrm{T}} \\
{\left[\mu \mathrm{mol} \mathrm{kg}{ }^{-1}\right]}\end{array}$ & $\begin{array}{l}\mathrm{C}_{\mathrm{T}} \\
{\left[\mu \mathrm{mol} \mathrm{kg}{ }^{-1}\right]}\end{array}$ & $\begin{array}{l}p \mathrm{CO}_{2} \\
{[\mu \mathrm{atm}]}\end{array}$ & $\begin{array}{l}\mathrm{CO}_{2} \\
{\left[\mu \mathrm{mol} \mathrm{kg}{ }^{-1}\right]}\end{array}$ & $\begin{array}{l}\mathrm{HCO}_{3}^{-} \\
{\left[\mu \mathrm{mol} \mathrm{kg}{ }^{-1}\right]}\end{array}$ & $\begin{array}{l}\mathrm{CO}_{3}^{2-} \\
{\left[\mu \mathrm{mol} \mathrm{kg}{ }^{-1}\right]}\end{array}$ & $\Omega_{\text {arag }}$ \\
\hline 1 (control) & $8.08 \pm 0.07$ & $2070.2 \pm 4.1$ & $1989.9 \pm 20.5$ & $480 \pm 81$ & $21.5 \pm 3.4$ & $1887.8 \pm 28.2$ & $80.6 \pm 11.2$ & $1.27 \pm 0.17$ \\
\hline 2 & $7.67 \pm 0.07$ & $1965.8 \pm 4.7$ & $1981.2 \pm 15.4$ & $1260 \pm 218$ & $55.7 \pm 8.8$ & $1894.1 \pm 11.2$ & $31.5 \pm 4.3$ & $0.49 \pm 0.07$ \\
\hline 3 & $7.49 \pm 0.05$ & $1922.6 \pm 5.1$ & $1977.4 \pm 14.9$ & $1859 \pm 240$ & $81.6 \pm 9.0$ & $1874.9 \pm 8.2$ & $20.9 \pm 1.9$ & $0.33 \pm 0.03$ \\
\hline 4 & $7.33 \pm 0.03$ & $1870.2 \pm 4.1$ & $1967.4 \pm 7.6$ & $2626 \pm 197$ & $115.4 \pm 6.6$ & $1837.9 \pm 3.8$ & $14.1 \pm 0.7$ & $0.22 \pm 0.01$ \\
\hline 5 & $7.28 \pm 0.03$ & $1854.8 \pm 3.1$ & $1967.1 \pm 8.0$ & $2903 \pm 204$ & $128.5 \pm 7.3$ & $1826.2 \pm 3.0$ & $12.5 \pm 0.6$ & $0.20 \pm 0.01$ \\
\hline 6 & $7.05 \pm 0.03$ & $1737.5 \pm 4.9$ & $1934.4 \pm 16.6$ & $4635 \pm 340$ & $206.0 \pm 18.5$ & $1721.5 \pm 4.0$ & $6.9 \pm 0.7$ & $0.11 \pm 0.01$ \\
\hline
\end{tabular}

conditions. The hatch rate varied between 66 and $96 \%$, except for one replicate of the highest treatment level having a hatch rate of only $48 \%$. However, no significant linear relationship between $p \mathrm{CO}_{2}$ level and hatch rate was found (Fig. $2 ; r^{2}=0.09, P=0.17$ ).

The elevated $p \mathrm{CO}_{2}$ conditions neither affected the total length ranging from 5.91 to $6.96 \mathrm{~mm}$ (Fig. $3 \mathrm{a} ; r^{2}=0.001$, $P=0.87$ ), the dry weight ranging from 38.8 to $54.3 \mu \mathrm{g}$ (Fig. $3 \mathrm{~b} ; r^{2}=0.07, P=0.23$ ), nor the yolk sac area ranging from 0.38 to $0.60 \mathrm{~mm}^{2}$ (Fig. $3 \mathrm{c} ; r^{2}=0.03, P=0.40$ ) of the newly hatched larvae.

The left and right otolith areas did not differ significantly from each other (paired t-test for sagitta and lapillus, respectively: $P>0.05$ ). The mean sagitta area varied from 371 to $470 \mu \mathrm{m}^{2}$ and the mean lapillus area from 314 to $419 \mu \mathrm{m}^{2}$. No significant linear relationship between the $p \mathrm{CO}_{2}$ level and the otolith area was found (sagitta: Fig. $4 \mathrm{a} ; r^{2}=0.02$, $P=0.47$; lapillus: Fig. $4 \mathrm{~b} ; r^{2}=0.10, P=0.13$ ), but a slight trend for greater lapillus area at higher $p \mathrm{CO}_{2}$ was observed.

In contrast to all the other examined parameters, the RNA/DNA ratio, ranging from 2.5 to 3.8 , was negatively affected by acidification (Fig. 5a; $r^{2}=0.47, P<0.01$, $\mathrm{y}=3.42-0.00019 \times \mathrm{x})$. The relative RNA content $(\mathrm{RNA} / \mathrm{dry}$ weight) was lowered significantly $\left(r^{2}=0.31, P<0.05\right.$, $\mathrm{y}=37.72-0.0019 \times \mathrm{x})$, while the relative DNA content (DNA/dry weight) was not affected $\left(r^{2}=0.02, P=0.62\right)$. However, a significant correlation could no longer be detected when excluding the highest treatment level from the statistical analysis (Fig. $5 b ; r^{2}=0.25, P=0.10$ ).

Calculated effect sizes and $95 \%$ confidence intervals around effect sizes for embryonic malformations, mortality rate during embryogenesis, hatch rate, total length, dry weight, yolk sac area, sagitta area, lapillus area and RNA/DNA ratio based on differences of control $\left(p \mathrm{CO}_{2} 480 \mu \mathrm{atm}\right)$ versus highest treatment $\left(p \mathrm{CO}_{2}\right.$ $4635 \mu \mathrm{atm}$ ) are presented in Fig. 6 . These showed clear overlap with zero for all variables tested, except for the lapillus area and the RNA/DNA ratio.

\section{Discussion}

\subsection{Effects on early development}

In this study we examined the effect of ocean acidification on the embryogenesis and the condition of newly hatched larvae of the Atlantic herring, Clupea harengus. We found no significant effect of elevated $p \mathrm{CO}_{2}$ on the occurence of embryonic malformations, the mortality rate of eggs, the embryonic duration, the hatch rate as well as the total length, dry weight, yolk sac area and otolith area at hatching based on linear regression analysis. The only parameters exhibiting a significant linear relationship were the RNA content and the RNA/DNA ratio, which decreased with increasing $p \mathrm{CO}_{2}$. Since non-significant results can be inconclusive (Fisher, 1935; Nakagawa and Foster, 2004), additional statistical support can be provided by $95 \%$ confidence intervals around statistical effect sizes (Nakagawa and Foster, 2004). When calculating effect sizes and $95 \%$ confidence intervals around effect sizes for embryonic malformation, egg mortality rate, hatch rate, total length, dry weight, yolk sac area and sagitta area at hatching a clear overlap with zero was found. Therefore, we concluded that the egg stage of $C$. harengus is tolerant to $p \mathrm{CO}_{2}$ levels up to $4635 \mu \mathrm{atm}$, exceeding future predictions of $\sim 4300 \mu \mathrm{atm}$ for Kiel Fjord (Thomsen et al., 2010). However, when using the effect size statistics a positive effect of ocean acidification on the lapillus area and a negative effect on the RNA/DNA ratio were shown.

Our results agree with those of Munday et al. (2009) who found no detectable effect on the embryonic duration, egg survival, hatch rate and size at hatching of the coral reef fish Amphiprion percula at $p \mathrm{CO}_{2}$ levels up to $1030 \mu \mathrm{atm}$. A. percula is a benthic spawner that lays clutches of eggs on hard surfaces in coral reefs where water $\mathrm{pH}$ varies during the day and sometimes reaches values below 8.0. Consequently, the eggs might be adapted to variations in ambient $p \mathrm{CO}_{2}$ levels (Munday et al., 2009). Herring spawns its benthic eggs on plant substrate or hard substrate during spring, when $p \mathrm{CO}_{2}$ reaches its minimum value $(385 \mu \mathrm{atm})$ in Kiel 
A

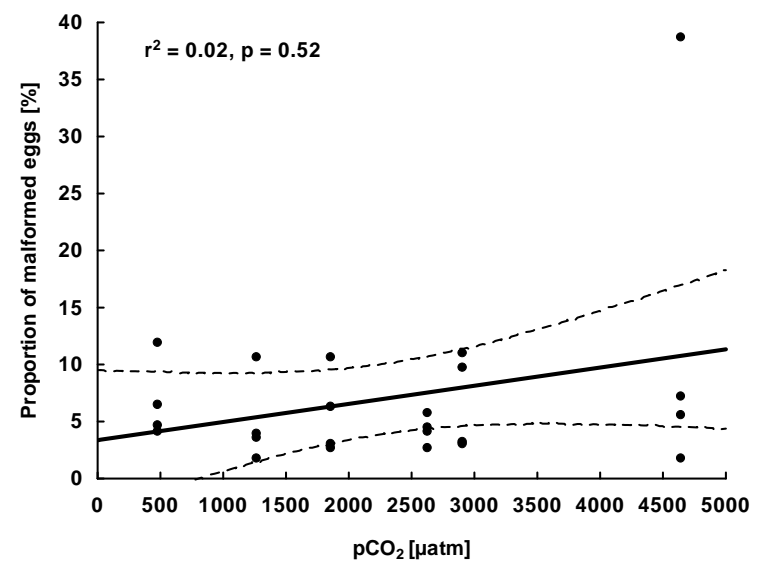

B

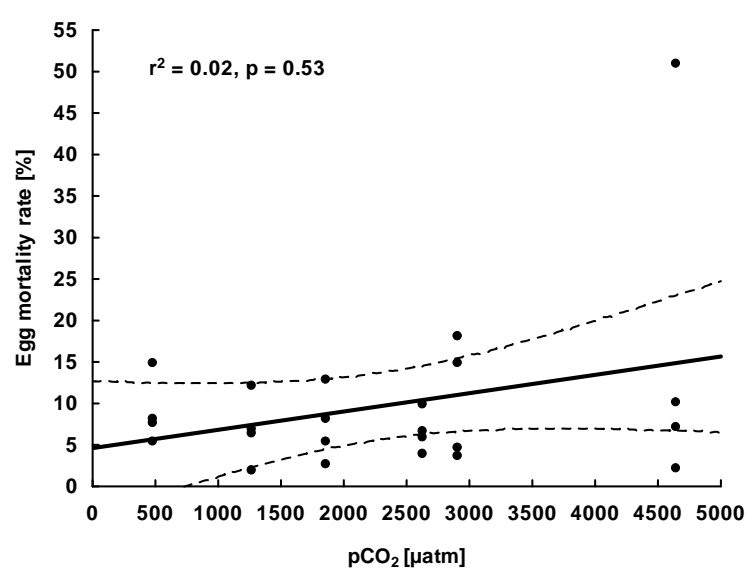

Fig. 1. (A) Proportion of malformed eggs and (B) mortality rate during the embryonic development as a function of $p \mathrm{CO}_{2}$ (4 replicates per treatment level). Data points are percentages of malformed eggs and mortality rates, respectively, of incubation plate 1 of the respective replicate. The solid line shows the regression line, whereas the dashed lines represent the $95 \%$ confidence intervals. The $r^{2}$ and $P$-value were derived from log-transformed data.

Fjord, however, the $p \mathrm{CO}_{2}$ of the surface water rises from spring to late summer up to a value of $2300 \mu$ atm (Thomsen et al., 2010). Thus, herring eggs and larvae develop under rising $p \mathrm{CO}_{2}$ conditions in Kiel fjord.

Gutowska and Melzner (2009) showed that $p \mathrm{O}_{2}$ in the perivitelline fluid of cephalopod (Sepia officinalis) eggs decrease during their embryonic development, while $p \mathrm{CO}_{2}$ increases reaching values tenfold higher than in ambient seawater. Accordingly, $\mathrm{pH}$ of the perivitelline fluid decreased to 7.2. A decrease of $p \mathrm{O}_{2}$ during the embryogenesis of shark (Scyliorhinus canicula) eggs was observed by Diez and Davenport (1987). Since the egg case serves as a diffusion barrier, high $p \mathrm{CO}_{2}$ values in developing fish eggs are expected

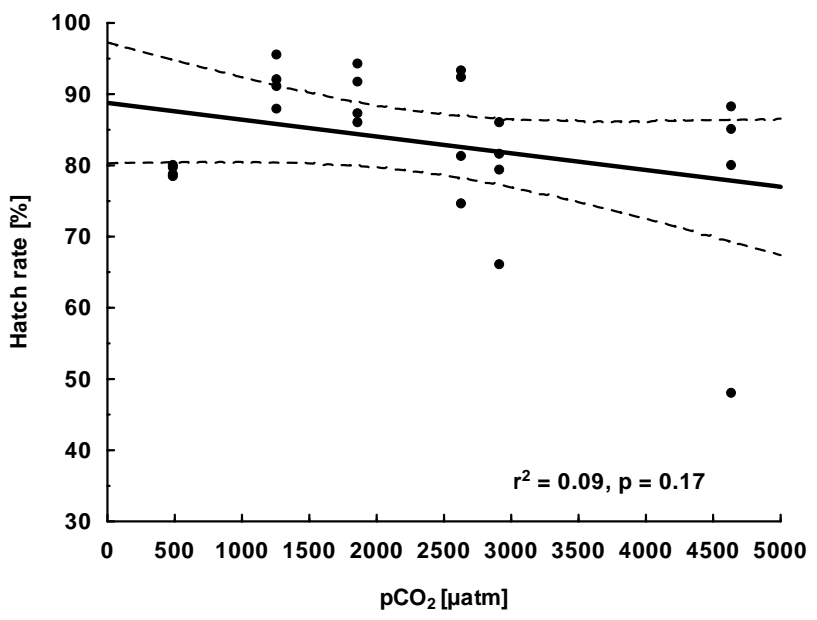

Fig. 2. Hatch rate (\%) of Atlantic herring eggs as a function of $p \mathrm{CO}_{2}$ (4 replicates per treatment level). Data points are percentages of hatched larvae of incubation plate 1 of the respective replicate. The solid line shows the regression line, whereas the dashed lines represent the $95 \%$ confidence intervals. The $r^{2}$ and $P$-value were derived from arcsine transformed data.

and powerful net proton excretion mechanisms should be present already in early developmental stages to cope with high perivitelline fluid $p \mathrm{CO}_{2}$ (Melzner et al., 2009). These mechanisms could possibly explain the observed capability of Atlantic herring eggs to cope with elevated $p \mathrm{CO}_{2}$ conditions.

Kikkawa et al. (2003) found the cleavage and juvenile stages of four teleost species to be the most susceptible to acute $\mathrm{CO}_{2}$ stress, the most tolerant stages being the embryo, preflexion and flexion stages. The reason for the ontogenetic changes in $\mathrm{CO}_{2}$ tolerance might be the development of ionregulatory chloride cells during the course of embryogenesis (Ishimatsu et al., 2004). While cleavage stages have no ionregulatory chloride cells, they have been found in the yolk sac membrane and body skin of embryos and larvae in various teleost species (Shiraishi et al., 1997; Hiroi et al., 1998; Katoh et al., 2000). Preliminary results from experiments in our laboratory indicate that these chloride cells are also found in herring embryos (Bodenstein and Clemmesen, 2011). The gradual fall in $\mathrm{CO}_{2}$ tolerance from larval to juvenile stage observed by Kikkawa et al. (2003) was also shown in Atlantic cod (Gadus morhua) by Frommel et al. (2011) and may result from the energy demanding transition from one acidbase regulatory site (yolk sac) to the other (gill) (Melzner et al., 2009). 
A

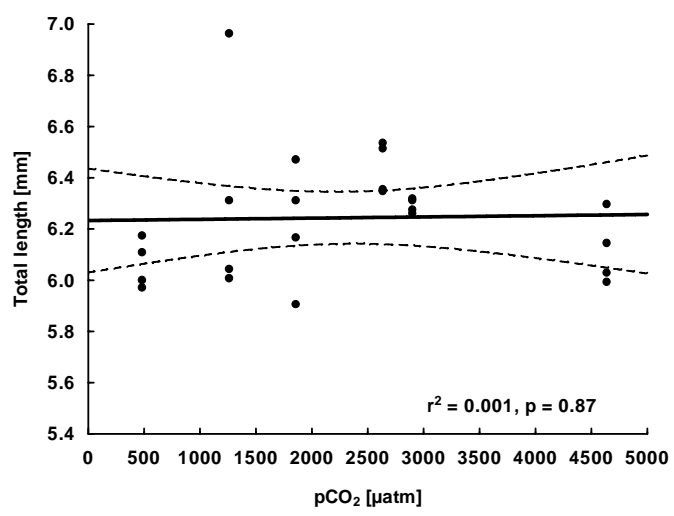

B

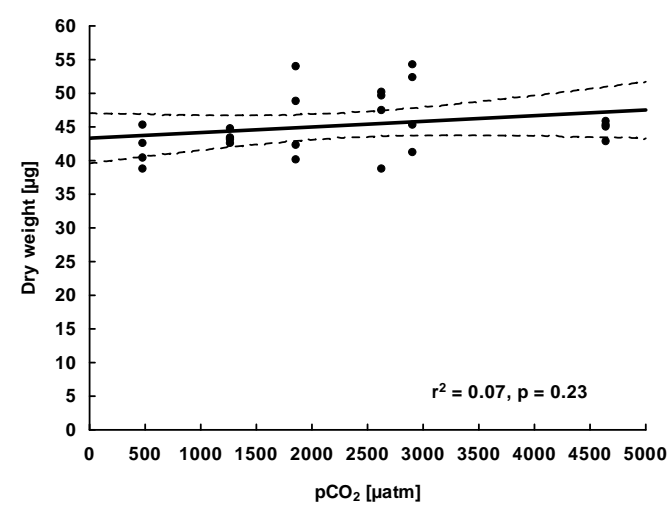

C

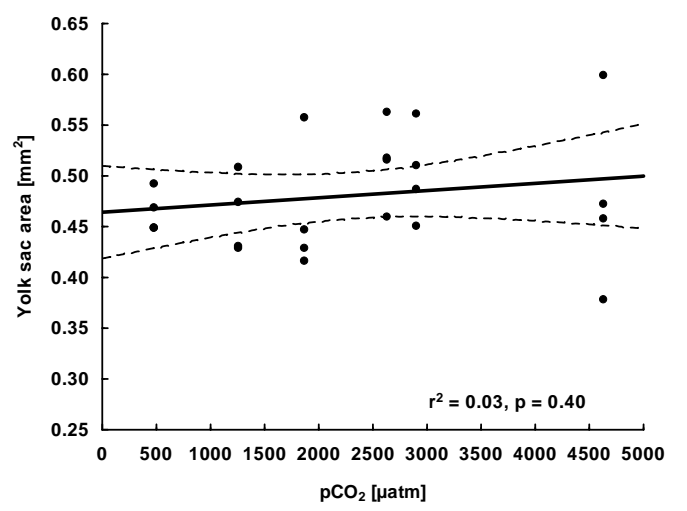

Fig. 3. (A) Total length, (B) dry weight and (C) yolk sac area of newly hatched Atlantic herring larvae as a function of $p \mathrm{CO}_{2}(4$ replicates per treatment level). Data points are mean values of 6 individual larvae. The solid line shows the regression line, whereas the dashed lines represent the $95 \%$ confidence intervals. (A) The $r^{2}$ and $P$-value were derived from log-transformed data.

\subsection{Biochemical indicator - RNA/DNA ratio}

Analyses of larval fish nucleic acid ratios provide a powerful tool to analyze and assess larval growth and condition (Clemmesen, 1994; Pepin et al., 1999; Buckley et al., 2008).
A

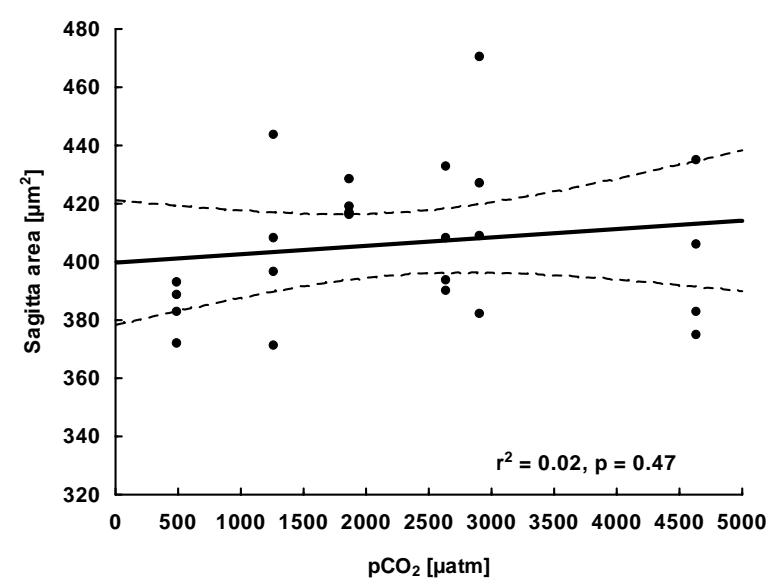

B

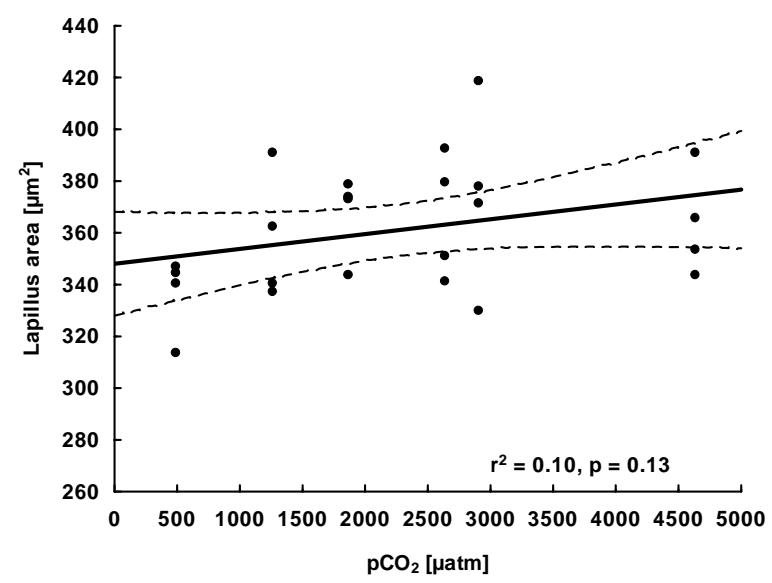

Fig. 4. (A) Sagitta area and (B) lapillus area of Atlantic herring larvae at hatch as a function of $p \mathrm{CO}_{2}$ (4 replicates per treatment level). Data points are mean values of 3 individual larvae (6 otoliths). The solid line shows the regression line, whereas the dashed lines represent the $95 \%$ confidence intervals.

The applicability of the nucleic acid ratio is based on the fact that DNA concentrations within individual cells remain fairly constant while RNA concentrations increase as protein synthesis increases (Buckley at al., 1999). The RNA/DNA ratio is therefore used as an indicator of protein biosynthesis and thus metabolic changes (e.g., Bulow, 1970; Buckley, 1984; Bergeron, 1997). It has been shown to be dependent on the nutritional condition and correlated to growth rate (Voss et al., 2006; Huwer et al., 2011). Hence, the RNA/DNA ratio allows to detect a change in the condition of fish larvae at the biochemical level before it can be observed at higher levels of biological organization (Sprague, 1971).

The RNA/DNA ratios of the newly hatched herring larvae were negatively affected by the increasing $p \mathrm{CO}_{2}$ level. Since 
A

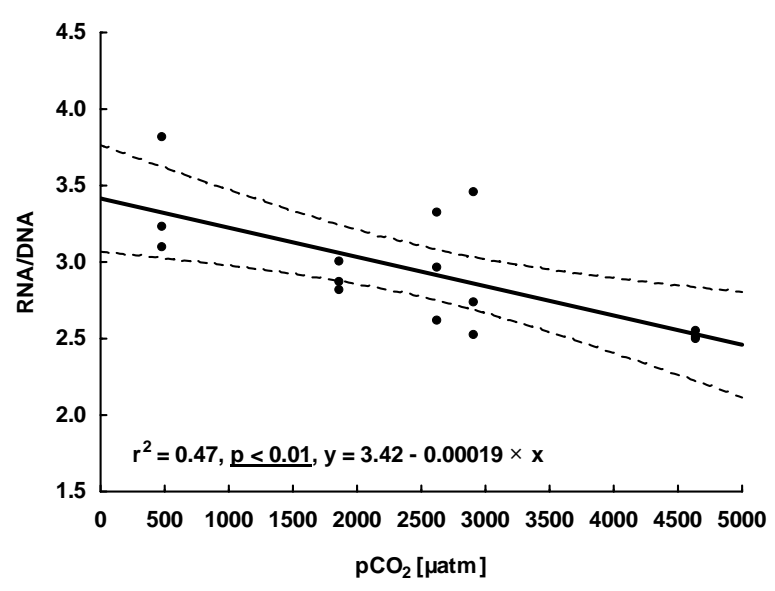

B

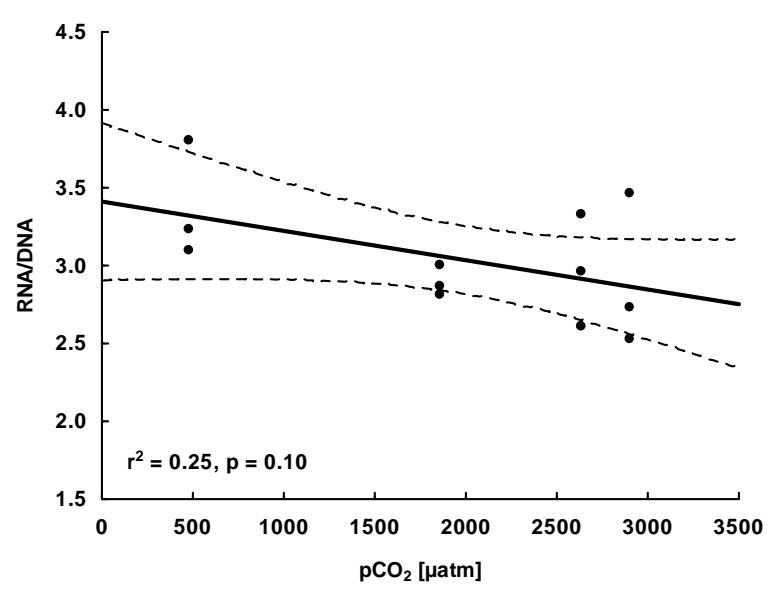

Fig. 5. (A) RNA/DNA ratio of newly hatched Atlantic herring larvae across the entire $p \mathrm{CO}_{2}$ gradient and $(\mathbf{B})$ without the highest treatment level. Due to accidental loss of samples larvae of only 3 replicates per treatment level could be used for nucleic acid determination. Furthermore, nucleic acids could not be examined for treatment level 2. Data points are mean values of 6 individual larvae. The solid line shows the regression line, whereas the dashed lines represent the $95 \%$ confidence intervals.

the DNA content per larval dry weight did not change in relation to the treatment levels, the number of cells per unit body weight was not affected. The change in the ratio was achieved by a reduction in the amount of RNA, indicating a decrease in protein biosynthesis. So far a reduction in growth and changes in the metabolic profile under hypercapnia have been shown in fish by Foss et al. (2003) in juvenile spotted wolffish (Anarhichas minor) and by Michaelidis et al. (2007) in adult gilthead seabream (Sparus aurata). Since the negative linear correlation could no longer be detected when the highest treatment level was deleted, a potential tipping point

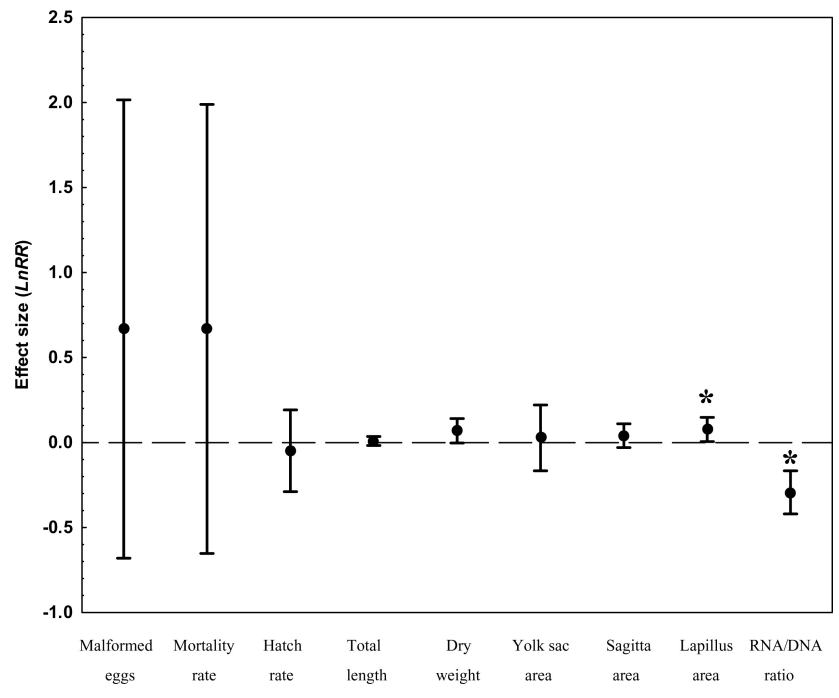

Fig. 6. Effect sizes and $95 \%$ confidence intervals for all examined variables (embryonic malformations, mortality rate of eggs, hatch rate and total length, dry weight, yolk sac area, sagitta area, lapillus area and RNA/DNA ratio of newly hatched Atlantic herring larvae) based on the differences between control $\left(p \mathrm{CO}_{2} 480 \mu \mathrm{atm}\right)$ and highest treatment $\left(~ p \mathrm{CO}_{2} 4635 \mu \mathrm{atm}\right)$. The effect size is significant when the $95 \%$ confidence interval does not overlap with zero $(*)$.

could be located between the two highest $p \mathrm{CO}_{2}$ levels (2903 and $4635 \mu \mathrm{atm})$.

Even though no effects on size and dry weight of newly hatched herring larvae were observed in this study, the question remains whether effects could appear later during the larval phase. Results on the impact of ocean acidification on Atlantic cod larvae from mesocosm experiments indicate that the stressor gradually shows an effect on the developing larvae and causes organ damage during transition phases (Frommel et al., 2011).

A reduction in growth as a result of a decreased protein biosynthesis could have large consequences for larval fish, since the smaller and slower growing individuals have a lower survival potential due to lower feeding success and increased mortality through predation (Houde, 1987, 2008; Anderson, 1988; Leggett and DeBlois, 1994). Pörtner et al. (2004, 2005) and Denman et al. (2011) concluded that reduced growth as a reaction to compensation for energy demanding regulatory mechanisms could lead to lower survival, lower reproductive potential and reduction in population size. 


\subsection{Effects on otoliths}

The otoliths (ear bones) are made of an aragonite structure within a protein matrix and are located in the labyrinth organ of fish. They are involved in sound detection, body orientation and acceleration based on their movement over sensory hairs. They are already formed during the embryonic development (Panella, 1971; Campana and Neilson, 1985) and any change in their size or shape could have implications for the ecological performance and individual fitness of the fish (Gagliano et al., 2008). Contrary to shells and exoskeletons of calcifying organisms, which are directly affected by chemical changes in the ambient seawater, the otoliths are protected in the inner ear of the fish. Therefore, the calcification process is dependent on the chemical composition of the endolymph (Borelli et al., 2003; Payan et al., 2004). In order to deposit aragonite in the protein matrix of the otoliths, the endolymph must be supersaturated with respect to aragonite (Romanek and Gauldie, 1996). Since the aragonite saturation state is correlated with the carbonate ion concentration, which is largely determined by $\mathrm{pH}$, endolymph $\mathrm{pH}$ regulation is needed for the aragonite crystallization (Takagi, 2002). Otolith growth may therefore be affected by mechanisms used to compensate extracellular $\mathrm{pH}$ decrease. It is noted that in our study the seawater carbonate chemistry was manipulated by adding acid. Compared to $\mathrm{CO}_{2}$-treated water this results in a decrease (instead of an increase) in the bicarbonate ion concentration and in a larger decrease in the carbonate ion concentration towards higher $p \mathrm{CO}_{2}$ levels. The bicarbonate ion concentration, however, remains high and should consequently not affect the ion-regulatory ability of the eggs and larvae.

There was a trend for a greater lapillus area at elevated $p \mathrm{CO}_{2}$ levels, but no significant relation could be found. However, when calculating the effect size a positive effect of ocean acidification on the lapillus area was shown, consistent with previous studies by Checkley et al. (2009) and Munday et al. (2011a). They concluded that $\mathrm{pH}$ regulation possibly caused the carbonate ion concentration to increase within the otolith endolymph. However, Munday et al. (2011b) found no effect on spiny damselfish (Acanthochromis polyacanthus) otoliths. Juvenile Sepia officinalis maintain calcification of the cuttlebone, a structure in the mantle of cuttlefish used for buoyancy control and functioning as an internal skeleton, under $p \mathrm{CO}_{2}$ levels as high as $\sim 6000 \mu \mathrm{atm}$ (Gutowska et al., 2008). During long-term exposure to elevated $p \mathrm{CO}_{2}$ concentrations calcification rates in Sepia officinalis even increased, but the spacing of the cuttlebone lamellae decreased which could possibly cause a negative influence on the animal's buoyancy (Gutowska et al., 2010).

The reason for the different responses of the sagitta and the lapillus to an increased $p \mathrm{CO}_{2}$ shown in our study is unknown. A possible explanation could be that the chemical composition of the endolymph is not spatially uniform. Payan et al. (1999) suggest that increasing bicarbonate and
$\mathrm{pH}$ gradients occur from the proximal to the distal zone in the saccular endolymph of trout (Oncorhynchus mykiss) and turbot (Psetta maxima). Thus, ionic gradients within the labyrinth organ might be the reason for the different responses of sagittal and lapillar otoliths.

\section{Conclusions and outlook}

Even though active taxa with high metabolic rates, such as teleosts and cephalopods, have the ability to compensate acid-base disturbances actively due to their efficient ionregulatory machinery, their early embryonic stages lack specialized ion-regulatory epithelia. Thus, they may be the true bottleneck for ecological success (Melzner et al., 2009).

The present study has shown that herring eggs can cope at current temperature conditions with an increase in $p \mathrm{CO}_{2}$, exceeding future predictions of $\mathrm{CO}_{2}$-driven ocean acidification, but that the yolk sac larvae show a reduced protein biosynthesis capacity and therefore a potential growth reduction. Since the recruitment of fish seems to be determined during the early life stages (Koester et al., 2003; Houde, 2008), knowledge of the factors influencing growth and survival rates of these stages are of great importance in fisheries science. Future studies should analyse carry-over effects that may be passed from adult to offspring and the synergistic effect of changes in $p \mathrm{CO}_{2}$ and temperature to be able to make predictions, how early life stages of fishes will react to climateinduced changes.

\section{Supplementary material related to this article is available online at: http://www.biogeosciences.net/8/3697/2011/ bg-8-3697-2011-supplement.zip.}

Acknowledgements. The authors wish to thank Sebastian Krug, Armin Form and Michael Meyerhöfer for their help and suggestions, Helgi Mempel and Jan Büdenbender for the laboratory work introduction and Uwe Waller for providing a part of the experimental setup. The study was partially supported through the European Community's Seventh Framework Programme (FP7/2007-2013) "European Project on Ocean Acidification" (EPOCA, grant agreement N211384) and the project "Biological Impacts of Ocean ACIDification" (BIOACID), funded by the German Ministry for Education and Research (BMBF).

Edited by: J.-P. Gattuso 


\section{References}

Anderson, J. T.: A review of size dependent survival during prerecruit stages of fishes in relation to recruitment, J. Northw. Atl. Fish. Sci., 8, 55-66, 1988.

Belchier, M., Clemmesen, C., Cortes, D., Doan, T., Folkvord, A., Garcia, A., Geffen, A., Høie, H., Johannessen, A., Moksness, E., de Pontual, H., Ramirez, T., Schnack, D., and Sveinsbo, B.: Recruitment studies: Manual on precision and accuracy of tools, ICES Tech. Mar. Environ. Sci., 33, 35 pp., 2004.

Bergeron, J. P.: Nucleic acids in ichthyoplankton ecology: a review, with emphasis of recent advances for new perspectives, J. Fish Biol., 51, 284-302, 1997.

Blaxter, J. H. S.: Herring rearing II. The effect of temperature and other factors on development, Mar. Res. Scot., 5, 19 pp., 1956.

Bodenstein, S. and Clemmesen, C.: Chloride cell distribution in early life stages in Atlantic herring (Clupea harengus L.), in prep., 2011.

Borelli, G., Guibbolini, M. E., Mayer-Gostan, N., Priouzeau, F., De Pontual, H., Allemand, D., Puverel, S., Tambutte, E., and Payan, P.: Daily variations of endolymph composition: relationship with the otolith calcification process in trout, J. Exp. Biol., 206, 26852692, 2003.

Buckley, L. J.: RNA-DNA ratio: an index of larval fish growth in the sea, Mar. Biol., 80, 291-298, 1984.

Buckley, L. J., Caldarone, E. M., and Ong, T. L.: RNA-DNA ratio and other nucleic-acid based indicators for growth and condition of marine fishes, Hydrobiol., 401, 265-277, 1999.

Buckley, L. J., Caldarone, E. M., and Clemmesen, C.: Multi-species larval fish growth model based on temperature and fluorometrically derived RNA/DNA ratios: results from a meta-analysis, Mar. Ecol. Prog. Ser., 371, 221-232, 2008.

Bulow, F. J.: RNA-DNA ratios as indicators of recent growth rates of a fish, J. Fish. Res. Bd. Can., 27, 2343-2349, 1970.

Caldarone, E. M., Clemmesen, C., Berdalet, E., Miller, T. J., Folkvord, A., Holt, G. J., Olivar, M. P., and Suthers, I. M.: Intercalibration of four spectrofluorometric protocols for measuring RNA/DNA ratios in larval and juvenile fish, Limnol. Oceanogr.Meth., 4, 153-163, 2006.

Campana, S. E. and Neilson, J. D.: Microstructure of fish otoliths, Can. J. Fish. Aquat. Sci., 42, 1014-1032, 1985.

Checkley, D. M., Dickson, A. G., Takahashi, M., Radich, J. A., Eisenkolb, N., and Asch, R.: Elevated $\mathrm{CO}_{2}$ enhances otolith growth in young fish, Science, 324, 1683, 2009.

Clemmesen, C.: Improvements in the fluorometric determination of the RNA and DNA content of individual marine fish larvae, Mar. Ecol. Prog. Ser., 100, 177-183, 1993.

Clemmesen, C.: The effect of food availability, age or size on the RNA/DNA ratio of individually measured herring larvae: laboratory calibration. Mar. Biol., 118, 377-382, 1994.

Conway, T. and Tans P., NOAA/ESRL, http://www.esrl.noaa.gov/ gmd/ccgg/trends/global.html, last access: November 2011.

Denman, K., Christian, J. R., Steiner, N., Pörtner H. O., and Nojiri, Y.: Potential impacts of future ocean acidification on marine ecosystems and fisheries: current knowledge and recommendations for future research, ICES J. Mar. Sci., 68, 1019-1029, 2011.

Dickson, A. G.: An exact definition of total alkalinity, and a procedure for the estimation of alkalinity and total inorganic carbon from titration data, Deep-Sea Res., 28, 609-623, 1981.

Diez, J. M. and Davenport, J.: Embryonic respiration in the spiny dogfish (Scyliorhinus canicula L.), J. Mar. Biol. Assoc. UK, 67, 249-261, 1987.

Doney, S. C., Fabry, V. J., Feely, R. A., and Kleypas, J. A.: Ocean acidification: The other $\mathrm{CO}_{2}$ problem, Annu. Rev. Mar. Sci., 1, 169-192, 2009.

Dupont, S. and Thorndyke, M. C.: Impact of $\mathrm{CO}_{2}$-driven ocean acidification on invertebrates early life-history - What we know, what we need to know and what we can do, Biogeosciences Discuss., 6, 3109-3131, doi:10.5194/bgd-6-3109-2009, 2009.

Dupont, S., Lundve, B., and Thorndyke, M.: Near future ocean acidification increases growth rate of the lecithotrophic larvae and juveniles of the sea star Crossaster papposus, J. Exp. Zool. (Mol. Dev. Evol.), 314B, 382-389, 2010.

Fabry, V. J.: Ocean science - marine calcifiers in a high- $\mathrm{CO}_{2}$ ocean, Science, 320, 1020-1022, 2008.

Feely, R. A., Sabine, C. L., Lee, K., Berelson, W., Kleypas, J., Fabry, V. J., and Millero, F. J.: Impact of anthropogenic $\mathrm{CO}_{2}$ on the $\mathrm{CaCO}_{3}$ system in the oceans, Science, 305, 362-366, 2004.

Feely, R. A., Sabine, C. L., Hernandez-Ayon, J. M., Ianson, D., and Hales, B.: Evidence for upwelling of corrosive "acidified" water onto the continental shelf, Science, 320, 1490-1492, 2008.

Fisher, R. A.: The design of experiments, Oliver and Boyd, Edinburgh, 1935.

Foss, A., Røsnes, B. A., and Øiestad, V.: Graded environmental hypercapnia in juvenile spotted wolffish (Anarhichas minor Olafsen): effects on growth, food conversion efficiency and nephrocalcinosis, Aquaculture, 220, 607-617, 2003.

Frommel, A. Y., Maneja, R., Lowe, D., Malzahn, A. M., Geffen, A. J., Folkvord, A., Piatkowski, U., Reusch, T. B. H., and Clemmesen, C.: Severe tissue damage in Atlantic cod larvae under increasing ocean acidification, Nature Clim. Change, doi:http://dx.doi.org/10.1038/NCLIMATE1324, 2011.

Gagliano, M., Depczynski, M., Simpson, S. D., and Moore, J. A. Y.: Dispersal without errors: Symmetrical ears tune into the right frequency for survival, Proc. R. Soc. B., 275, 527-534, 2008.

Gattuso, J.-P. and Hansson, L.: Ocean acidification: background and history, 1-20, in: Ocean acidification, edited by: Gattuso, J.-P. and Hansson, L., Oxford: Oxford University Press, 326 pp., 2011.

Gattuso, J.-P., Lee, K., Rost, B., Schulz, K., and Gao, K.: Approaches and tools to manipulate the carbonate chemistry, 4152, in: Guide to best practices for ocean acidification research and data reporting, edited by: Riebesell U., Fabry V. J., Hansson L., and Gattuso J.-P., Luxembourg: Publications Office of the European Union, 260 pp., 2010.

Gutowska, M. A. and Melzner, F.: Abiotic conditions in cephalopod (Sepia officinalis) eggs: Embryonic development at low $\mathrm{pH}$ and high $p \mathrm{CO}_{2}$, Mar. Biol., 156, 515-519, 2009.

Gutowska, M. A., Pörtner, H. O., and Melzner, F.: Growth and calcification in the cephalopod Sepia officinalis under elevated seawater $p \mathrm{CO}_{2}$, Mar. Ecol. Prog. Ser., 373, 303-309, 2008.

Gutowska, M. A., Melzner, F., Langenbuch, M., Bock, C., Claireaux, G., and Pörtner, H. O.: Acid-base regulatory ability of the cephalopod (Sepia officinalis) in response to environmental hypercapnia, J. Comp. Physiol. B, 180, 323-335, 2010.

Hedges, L. V. and Olkin, I.: Statistical methods for meta-analysis, Academic Press, Orlando, FL, 369 pp., 1985.

Hiroi, J., Kaneko, T., Seikai, T., and Tanaka, M.: Developmental sequence of chloride cells in the body skin and gills of Japanese 
flounder (Paralichthys olivaceus) larvae, Zool. Sci., 15, 455-460, 1998.

Houde, E. D.: Fish early life dynamics and recruitment variability, Am. Fish. Soc. Symp., 2, 17-29, 1987.

Houde, E. D.: Emerging from Hjort's Shadow, J. Northw. Atl. Fish. Sci., 41, 53-70, 2008.

Hu, M. Y., Tseng, Y. C., Stumpp, M., Gutowska, M. A., Kiko, R., Lucassen, M., and Melzner, F.: Elevated seawater $p \mathrm{CO}_{2}$ differentially affects branchial acid-base transporters over the course of development in the cephalopod Sepia officinalis, Ame. J. Physiol.-Reg. I., 300, R1100-R1114, 2011.

Huwer, B., Clemmesen, C., Gronkjaer, P., and Koester, F. W.: Vertical distribution and growth performance of Baltic cod larvae Field evidence for starvation-induced recruitment regulation during the larval stage?, Prog. Oceanogr., 91, 382-396, 2011.

Ishimatsu, A., Kikkawa, T., Hayashi, M., Lee, K. S., and Kita, J.: Effects of $\mathrm{CO}_{2}$ on marine fish: Larvae and adults, J. Oceanogr., 60, 731-741, 2004.

Ishimatsu, A., Hayashi, M., and Kikkawa, T.: Fishes in high- $\mathrm{CO}_{2}$, acidified oceans, Mar. Ecol. Prog. Ser., 373, 295-302, 2008.

Katoh, F., Shimizu, A., Uchida, K., and Kaneko, T.: Shift of chloride cell distribution during early life stages in seawater-adapted killifish, Fundulus heteroclitus, Zool. Sci., 17, 11-18, 2000.

Kikkawa, T., Ishimatsu, A., and Kita, J.: Acute $\mathrm{CO}_{2}$ tolerance during the early developmental stages of four marine teleosts, Environ. Toxicol., 18, 375-382, 2003.

Koester, F. W., Hinrichsen, H. H., Schnack, D., St John, M. A., Mackenzie, B. R., Tomkiewicz, J., Möllmann, C., Kraus, G., Plikshs, M., Makarchouk, A., and Aro, E.: Recruitment of Baltic cod and sprat stocks: identification of critical life stages and incorporation of environmental variability into stock-recruitment relationships, Sci. Mar., 67, 129-154, 2003.

Kroeker, K. J., Kordas, R. L., Crim, R. N., and Singh, G. G.: Metaanalysis reveals negative yet variable effects of ocean acidification on marine organisms, Ecol. Lett., 13, 1419-1434, 2010.

Langdon, C.: Review of experimental evidence for effects of $\mathrm{CO}_{2}$ on calcification of reef-builders, Proc. 9th Int. Coral Reef Sym., 2, 1091-1098, 2002.

Larsen, B. K., Pörtner, H. O., and Jensen, F. B.: Extra- and intracellular acid-base balance and ionic regulation in cod (Gadus morhua) during combined and isolated exposures to hypercapnia and copper, Mar. Biol., 128, 337-346, 1997.

Leggett, W. C. and DeBlois, E.: Recruitment in marine fishes: is it regulated by starvation and predation in the egg and larval stages?, Neth. J. Sea Res., 32, 119-134, 1994.

Le Pecq, J. B. and Paoletti, C.: A new fluorometric method for RNA and DNA determination, Anal. Biochem., 17, 100-107, 1966.

Malzahn, A. M., Clemmesen, C., Wiltshire, K. H., Laakmann, S., and Boersma, M.: Comparative nutritional condition of larval dab Limanda limanda and lesser sandeel Ammodytes marinus in a highly variable environment, Mar. Ecol. Prog. Ser., 334, 205212, 2007

Melzner, F., Gutowska, M. A., Langenbuch, M., Dupont, S., Lucassen, M., Thorndyke, M. C., Bleich, M., and Pörtner, H. O.: Physiological basis for high $\mathrm{CO}_{2}$ tolerance in marine ectothermic animals: pre-adaptation through lifestyle and ontogeny?, Biogeosciences, 6, 2313-2331, doi:10.5194/bg-6-2313-2009, 2009.

Michaelidis, B., Spring, A., and Pörtner, H. O.: Effects of long-term acclimation to environmental hypercapnia on extracellular acid- base status and metabolic capacity in mediterranean fish Sparus aurata, Mar. Biol., 150, 1417-1429, 2007.

Munday, P. L., Donelson, J. M., Dixson, D. L., and Endo, G. G. K.: Effects of ocean acidification on the early life history of a tropical marine fish, P. Roy. Soc. B-Biol. Sci., 276, 3275-3283, 2009.

Munday, P. L., Hernaman, V., Dixson, D. L., and Thorrold, S. R.: Effect of ocean acidification on otolith development in larvae of a tropical marine fish, Biogeosciences, 8, 1631-1641, doi:10.5194/bg-8-1631-2011, 2011a.

Munday, P. L., Gagliano, M., Donelson, J. M., Dixson, D. L., and Thorrold, S. R.: Ocean acidification does not affect the early life history development of a tropical marine fish, Mar. Ecol. Prog. Ser., 423, 211-221, $2011 \mathrm{~b}$.

Nakagawa, S. and Foster, T. M.: The case against retrospective statistical power analyses with an introduction to power analysis, Acta. Ethol., 7, 103-108, 2004.

Orr, J. C.: Recent and future changes in ocean carbonate chemistry, 41-66, in: Ocean acidification, edited by: Gattuso, J.-P. and Hansson, L., Oxford, Oxford University Press, 326 pp., 2011.

Panella, G.: Fish otolith: Daily layers and periodical patterns, Science, 173, 1124-1127, 1971.

Payan, P., Edeyer, A., De Pontual, H., Borelli, G., Boeuf, G., and Mayer-Gostan, N.: Chemical composition of saccular endolymph and otolith in fish inner ear: Lack of spatial uniformity, Am. J. Physiol.-Reg. I., 277, R123-R131, 1999.

Payan, P., De Pontual, H., Boeuf, G., and Mayer-Gostan, N.: Endolymph chemistry and otolith growth in fish, C. R. Palevol., 3, 535-547, 2004.

Pepin, P., Evans, G. T., and Shears, T. H.: Patterns of RNA/DNA ratios in larval fish and their relationship to survival in the field, ICES J. Mar. Sci., 56, 697-706, 1999.

Pierrot, D., Lewis, E., and Wallace, D. W. R.: MS Excel program developed for $\mathrm{CO}_{2}$ system calculations. Macro for low salinities, Carbon Dioxide Information Analysis Center, Oak Ridge National Laboratory, US Department of Energy, Oak Ridge, Tennessee, 2006.

Pörtner, H. O. and Peck, M. A.: Climate change effects on fishes and fisheries: Towards a cause-and-effect understanding, J. Fish Biol., 77, 1745-1779, 2010.

Pörtner, H. O., Langenbuch, M., and Reipschlaeger, A.: Biological impact of elevated ocean $\mathrm{CO}_{2}$ concentrations: Lessons from animal physiology and earth history, J. Oceanogr., 60, 705-718, 2004.

Pörtner, H. O., Langenbuch, M., and Michaelidis, B.: Synergistic effects of temperature extremes, hypoxia, and increases in $\mathrm{CO}_{2}$ on marine animals: From earth history to global change, J. Geophys. Res.-Oceans, 110, C09S10, doi:10.1029/2004jc002561, 2005.

Raven, J., Caldeira, K., Elderfield, H., Hoegh-Guldberg, O., Liss, P. S., Riebesell, U., Shepherd, J., Turley, C., and Watson, A. J.: Ocean acidification due to increasing atmospheric carbon dioxide, Policy Document 12/05, London, The Royal Society, 60 pp., 2005.

Ries, J. B., Cohen, A. L., and McCorkle, D. C.: Marine calcifiers exhibit mixed responses to $\mathrm{CO}_{2}$-induced ocean acidification, $\mathrm{Ge}$ ology, 37, 1131-1134, 2009.

Romanek, C. S. and Gauldie, R. W.: A predictive model of otolith growth in fish based on the chemistry of the endolymph, Comp. 
Biochem. Physiol. A, 114, 71-79, 1996.

Rosenthal, H. and Alderdice, D. F.: Sublethal effects of environmental stressors, natural and pollutional, on marine fish eggs and larvae, J. Fish. Res. Board Can., 33, 2047-2065, 1976.

Roy, R. N., Roy, L. N., Vogel, K. M., Portermoore, C., Pearson, T., Good, C. E., Millero, F. J., and Campbell, D. M.: The dissociation constants of carbonic acid in seawater at salinities 5 to 45 and temperatures 0 to $45^{\circ} \mathrm{C}$, Mar. Chem., 44, 249-267, 1993.

Shiraishi, K., Kaneko, T., Hasegawa, S., and Hirano, T.: Development of multicellular complexes of chloride cells in the yolk-sac membrane of tilapia (Oreochromis mossambicus) embryos and larvae in seawater, Cell Tissue Res., 288, 583-590, 1997.

Siegenthaler, U., Stocker, T. F., Monnin, E., Lüthi, D., Schwander, J., Stauffer, B., Raynaud, D., Barnola, J.-M., Fischer, H., Masson-Delmotte, V., and Jouzel, J.: Stable carbon cycle-climate relationship during the late Pleistocene, Science, 310, 13131317, 2005.

Sprague, J. B.: Measurement of pollutant toxicity to fish III. Sublethal effects and "safe" concentrations, Water Res., 5, 245-266, 1971.
Stoll, M. H. C., Bakker, K., Nobbe, G. H., and Haese, R. R.: Continuous-flow analysis of dissolved inorganic carbon content in seawater, Anal. Chem., 73, 4111-4116, 2001.

Takagi, Y.: Otolith formation and endolymph chemistry: a strong correlation between the aragonite saturation state and $\mathrm{pH}$ in the endolymph of the trout otolith organ, Mar. Ecol. Prog. Ser., 231, 237-245, 2002.

Thomsen, J., Gutowska, M. A., Saphörster, J., Heinemann, A., Trübenbach, K., Fietzke, J., Hiebenthal, C., Eisenhauer, A., Körtzinger, A., Wahl, M., and Melzner, F.: Calcifying invertebrates succeed in a naturally $\mathrm{CO} 2$-rich coastal habitat but are threatened by high levels of future acidification, Biogeosciences, 7, 3879-3891, doi:10.5194/bg-7-3879-2010, 2010.

Voss, R., Clemmesen, C., Baumann, H., and Hinrichsen, H.-H.: Baltic sprat larvae: Coupling food availability, larval condition and survival, Mar. Ecol. Prog. Ser., 308, 243-254, 2006. 